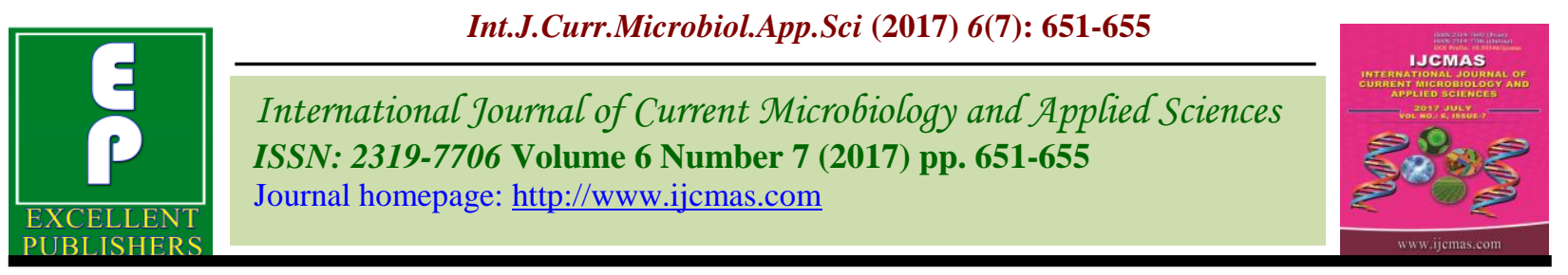

Original Research Article

https://doi.org/10.20546/ijcmas.2017.607.079

\title{
Use of Biocontrol Agents: A Potential Alternative to Fungicides for Fusarium Wilt Management of Banana
}

\author{
Y. Pushpavathi* and S.N. Dash \\ College of Agriculture, Orissa University of Agriculture and Technology \\ Bhubaneswar, Odisha, India \\ *Corresponding author
}

\begin{tabular}{|c|c|}
\hline & A B S T R A C T \\
\hline & Banana is the staple food for millions of people in the developing countries of \\
\hline Keywords & $\begin{array}{l}\text { tropics. Among the production constraints, Fusarium wilt caused by the fungus } \\
\text { Fusarium oxysporum f. sp cubense (Foc) is the most devastating disease affecting }\end{array}$ \\
\hline $\begin{array}{l}\text { Biocontrol agents, } \\
\text { Fungicides, } \\
\text { Fusarium wilt } \\
\text { management } \\
\text { and banana. }\end{array}$ & $\begin{array}{l}\text { commercial and subsistence of banana production throughout the banana } \\
\text { producing areas of the world. Biological control of Fusarium wilt disease has } \\
\text { become an increasingly popular disease management consideration because of its } \\
\text { environmental friendly nature which offers a potential alternative to the use of }\end{array}$ \\
\hline Article Info & fungicides. The experiment was conducted at the Horticultural Research Station, \\
\hline $\begin{array}{l}\text { Accepted: } \\
\text { 14 June } 2017 \\
\text { Available Online: } \\
10 \text { July } 2017\end{array}$ & $\begin{array}{l}\text { efficacy of biocontrol agents and fungicides in fusarium wilt management. Sucker } \\
\text { treatment before planting and soil drenching twice at } 60 \text { and } 180 \text { DAP with } \\
\text { biocontrol agents Trichoderma viride and Pseudomonas fluorescens found to be } \\
\text { the most effective treatment in reducing the disease incidence and intensity. }\end{array}$ \\
\hline
\end{tabular}

\section{Introduction}

Fusarium wilt of banana (Musa spp.) caused by Fusarium oxysporum f. sp. cubense is a serious and destructive disease on many cultivars in the world (Stover, 1962; Alves et al., 1987; Ploetz et al., 1990). It is a classic vascular wilt disease in which the fungus gains entry to the water conducting xylem vessels, then proliferates within the vessels causing water blockage. The typical symptoms include wilting and death of the leaves, followed by death of the whole plant. Since the discovery of Fusarium wilt of banana, though various control strategies like soil fumigation (Herbert and Marx, 1990); fungicides (Lakshmanan et al., 1987); crop rotation (Hwang, 1985; Su et al., 1986), flood -fallowing (Wardlaw, 1961) and organic amendments (Stover, 1962) have been evolved and attempted, yet, the disease could not be controlled effectively except by planting of resistant cultivars (Moore et al., 1999). Planting of resistant varieties also cannot be implemented because of consumer preference (Viljoen, 2002). Under these circumstances, use of antagonistic microbes which protect and promote plant growth by colonizing and multiplying in both rhizosphere and plant system could be a potential alternative approach for the management of Fusarium wilt of banana. 
Several reports have previously demonstrated the successful use different species of Trichoderma, Pseudomonas for fusarium wilt management (Alabouvette et al., 1993; Thangavelu et al., 2001; Rajappan et al., 2002). In the present experiment different fungicides, biocontrol agents, Trichoderma viride, Pseudomonas fluorescens and neem cake were evaluated for their efficacy against Fusarium wilt of banana.

\section{Materials and Methods}

The investigation was carried out at the Horticultural Research Station, Orissa University of Agriculture and Technology during 2013-15. The location of the experimental plot is at a distance of $60 \mathrm{~km}$ from Bay of Bengal with latitude and longitude of $20^{\circ} 15^{\prime}$ and $85^{\circ} 52^{\prime}$, respectively. The experiment was laid out in complete randomized block design with ten treatments replicated thrice. Each treatment in a replication comprised of five banana plants. Fusarium wilt infected one month old suckers of cv. Bantal verified from laboratory were used as planting material. The different treatments comprised of fungicides, biocontrol agents and neem cake used through sucker treatment, soil drenching and soil application methods. Suckers were planted at $2.2 \mathrm{~m} \times 2.2 \mathrm{~m}$ spacing.

\section{Details of treatments}

$\mathrm{T}_{1}$ : Sucker treatment for 30 minutes with Carbendazim $50 \mathrm{WP} 0.2 \%+$ Blitox $50 \mathrm{WP} 0.3 \%+$ Bleaching powder $0.015 \%$.

$\mathrm{T}_{2}$ : $\quad$ Sucker treatment for 30 minutes with Captan $50 \mathrm{WP} 0.3 \%+$ Vitavax power $75 \mathrm{WP} 0.5 \%+$ Bleaching powder $0.015 \%$.

$\mathrm{T}_{3}$ : $\quad$ Sucker treatment with Trichoderma viride + Pseudomonas fluorescens @ $20 \mathrm{~g}^{-1}$ for $30 \mathrm{~min}$.

$\mathrm{T}_{4}$ : $\quad \mathrm{T}_{1}+$ Soil drenching with $\mathrm{T}_{1}$ chemicals at 60 days after planting (DAP) and $180 \mathrm{DAP}$

$\mathrm{T}_{5}: \quad \mathrm{T}_{2}+$ Soil drenching with $\mathrm{T}_{2}$ chemicals at 60 and $180 \mathrm{DAP}$

$\mathrm{T}_{6}: \quad \mathrm{T}_{3}+$ Soil drenching with Trichoderma viride + Pseudomonas fluorescens at 60 and $180 \mathrm{DAP}$

$\mathrm{T}_{7}$ : $\mathrm{T}_{4}+$ soil drenching with $\mathrm{T}_{2}$ chemical alternatively at $60 \mathrm{DAP}$ and $180 \mathrm{DAP}$

$\mathrm{T}_{8}$ : $\quad$ Soil application with Trichoderma viride+ Pseudomonas fluorescens at 30 and 180 DAP

$\mathrm{T}_{9}$ : Neem cake application @ $250 \mathrm{~kg} / \mathrm{ha}$ at planting and $180 \mathrm{DAP}$

$\mathrm{T}_{10}$ : Control (no treatment)

Suckers were dipped in different fungicidal and biocontrol solutions for 30 minutes and dried in shade. For soil application of biocontrol agents $200 \mathrm{~g}$ of fresh stock of each $T$. viride and $P$. fluorescens were mixed separately with $20 \mathrm{~kg}$ of well rotten and powdered FYM with addition of sufficient quantity of water. These mixtures were covered with polyethylene sheet for two days. Every day the mixtures were stirred thoroughly by sprinkling water to maintain the moisture content around 30 per cent up to 21 days for better growth of biocontrol organisms. After this period of incubation the mixtures were applied to the base of the banana plants evenly@10 quintals/ha one month after planting and was repeated after six months around which the disease symptoms appeared in most of the plants. Similarly neem cake was used as soil application in $\mathrm{T}_{9}$. Well powdered neem cake was applied at the base of the plants evenly @ $250 \mathrm{~kg} / \mathrm{ha}$ at the time of planting and repeated six months after. Soil drenching of chemicals was carried out around the base of the plants twice i.e. two and six months after planting. To ensure the full incidence of wilt disease in the test plants chopped, rhizomes and some 
soil from around heavily wilt infected plants were applied to the base two months after planting. Samples were analysed in laboratory for confirmation of the disease incidence. Observations on disease characters like plants showing prominent symptoms (drooping of older leaves with complete yellowing, splitting of psuedostem) percentage of leaf area affected by wilt disease, percentage of dead leaves. Quantitative data recorded in the experiment have been statistically analysed as procedures outlined by Panse and Sukhatme (1985).

\section{Results and Discussion}

The treatment consisted of sucker treatment and soil drenching with biocontrol agents Trichoderma viride and Pseudomonas fluorescens at 60 and 180 DAP recorded lowest mean percentage $(27.78 \%)$ of plants with prominent symptoms followed by only soil application of both bioagent (35.55\%). Control plots recorded highest infection of $86.67 \%$ (Table 1). Similar reports have been observed by Sivamani and Gnanamanikyam (1988). Lowest percentage (31.33\%) of disease affected area in leaves was recorded in the plants sucker treated and soil drenched with biocontrol agents followed by only soil application of both bioagents (33.19\%), whereas control plants showed highest percentage of $(44.90 \%)$ disease affected area in leaves. Dowling and O'Gara (1994) also obtained similar results where they could obtain antifungal metabolites from $P$. fluorescens which caused inhibition of fungal cell multiplication of the pathogenic fungi.

Table.1 Effect of biocontrol agents and fungicides on per cent plants with prominent symptoms and of disease affected area of leaves in a plant

\begin{tabular}{|c|c|c|c|c|c|c|c|c|}
\hline \multirow[t]{2}{*}{ Treatment } & \multicolumn{4}{|c|}{$\begin{array}{l}\text { Per cent plants showing prominent wilt } \\
\text { symptoms }\end{array}$} & \multicolumn{4}{|c|}{$\begin{array}{l}\text { Per cent of disease affected area of leaves in a } \\
\text { plant }\end{array}$} \\
\hline & 270 DAP & $\begin{array}{l}315 \\
\text { DAP }\end{array}$ & 360 DAP & Mean & 270DAP & 315 AP & 360 DAP & Mean \\
\hline $\mathbf{T}_{1}$ & $\begin{array}{l}46.67 \\
(43.08)\end{array}$ & $\begin{array}{l}40.00 \\
(39.23)\end{array}$ & $\begin{array}{l}53.67 \\
(47.10)\end{array}$ & 46.67 & $\begin{array}{l}47.87 \\
(43.77)\end{array}$ & $\begin{array}{l}33.20 \\
(35.17)\end{array}$ & $\begin{array}{l}30.90 \\
(33.74)\end{array}$ & 37.32 \\
\hline $\mathbf{T}_{2}$ & $\begin{array}{l}33.33 \\
(38.85)\end{array}$ & $\begin{array}{l}40.00 \\
(39.23)\end{array}$ & $\begin{array}{l}41.00 \\
(39.82)\end{array}$ & 37.78 & $\begin{array}{l}41.87 \\
(40.30)\end{array}$ & $\begin{array}{l}32.00 \\
(34.46)\end{array}$ & $\begin{array}{l}37.30 \\
(37.54)\end{array}$ & 37.06 \\
\hline $\mathbf{T}_{3}$ & $\begin{array}{l}53.33 \\
(46.92)\end{array}$ & $\begin{array}{l}46.67 \\
(43.08)\end{array}$ & $\begin{array}{l}40.33 \\
(39.43)\end{array}$ & 48.89 & $\begin{array}{l}45.80 \\
(42.59)\end{array}$ & $\begin{array}{l}33.20 \\
(35.17)\end{array}$ & $\begin{array}{l}40.00 \\
(39.36)\end{array}$ & 39.67 \\
\hline $\mathbf{T}_{4}$ & $\begin{array}{l}60.00 \\
(50.77)\end{array}$ & $\begin{array}{l}40.00 \\
(39.23)\end{array}$ & $\begin{array}{l}39.67 \\
(39.04)\end{array}$ & 46.67 & $\begin{array}{l}48.47 \\
(44.11)\end{array}$ & $\begin{array}{l}34.70 \\
(36.05)\end{array}$ & $\begin{array}{l}32.10 \\
(34.51)\end{array}$ & 38.42 \\
\hline $\mathbf{T}_{5}$ & $\begin{array}{l}53.33 \\
(46.92)\end{array}$ & $\begin{array}{l}46.67 \\
(43.08)\end{array}$ & $\begin{array}{l}31.33 \\
(34.06)\end{array}$ & 46.67 & $\begin{array}{l}49.97 \\
(44.96)\end{array}$ & $\begin{array}{l}33.00 \\
(35.08)\end{array}$ & $\begin{array}{l}33.30 \\
(35.19)\end{array}$ & 38.76 \\
\hline$T_{6}$ & $\begin{array}{l}26.67 \\
(30.78)\end{array}$ & $\begin{array}{l}26.67 \\
(30.78)\end{array}$ & $\begin{array}{l}30.00 \\
(33.21)\end{array}$ & 27.78 & $\begin{array}{l}35.90 \\
(36.74)\end{array}$ & $\begin{array}{l}28.90 \\
(32.48)\end{array}$ & $\begin{array}{l}29.20 \\
(32.68)\end{array}$ & 31.33 \\
\hline $\mathbf{T}_{7}$ & $\begin{array}{l}53.33 \\
(46.92)\end{array}$ & $\begin{array}{l}40.00 \\
(39.23)\end{array}$ & $\begin{array}{l}45.33 \\
(42.27)\end{array}$ & 46.67 & $\begin{array}{l}49.77 \\
(44.87)\end{array}$ & $\begin{array}{l}35.70 \\
(36.63)\end{array}$ & $\begin{array}{l}41.10 \\
(39.29)\end{array}$ & 42.19 \\
\hline $\mathbf{T}_{8}$ & $\begin{array}{l}33.33 \\
(35.01)\end{array}$ & $\begin{array}{l}33.33 \\
(35.01)\end{array}$ & $\begin{array}{l}36.00 \\
(36.87)\end{array}$ & 35.55 & $\begin{array}{l}38.37 \\
(38.27)\end{array}$ & $\begin{array}{l}31.00 \\
(33.76)\end{array}$ & $\begin{array}{l}30.20 \\
(33.21)\end{array}$ & 33.19 \\
\hline $\mathbf{T}_{9}$ & $\begin{array}{l}73.33 \\
(59.22) \\
\end{array}$ & $\begin{array}{l}60.00 \\
(50.77) \\
\end{array}$ & $\begin{array}{l}72.00 \\
(58.00)\end{array}$ & 68.89 & $\begin{array}{l}54.57 \\
(47.68) \\
\end{array}$ & $\begin{array}{l}36.60 \\
(37.23)\end{array}$ & $\begin{array}{l}36.00 \\
(36.84)\end{array}$ & 42.39 \\
\hline$T_{10}$ & $\begin{array}{l}80.00 \\
(63.44)\end{array}$ & $\begin{array}{l}80.00 \\
(63.44)\end{array}$ & $\begin{array}{l}100.00 \\
(90.00)\end{array}$ & 86.67 & $\begin{array}{l}55.40 \\
(48.13)\end{array}$ & $\begin{array}{l}35.40 \\
(41.55)\end{array}$ & $\begin{array}{l}43.90 \\
(41.49)\end{array}$ & 44.90 \\
\hline SEm \pm & 3.946 & 2.662 & 3.65 & & 1.908 & 1.317 & 1.710 & \\
\hline C.D. 0.05 & 11.725 & 7.910 & 10.85 & & 5.670 & 3.912 & 5.079 & \\
\hline
\end{tabular}

Note: Data in the parentheses indicate angular transformed values 
Table.2 Effect of biocontrol agents and fungicides on per cent dead leaves in a plant

\begin{tabular}{|c|c|c|c|c|}
\hline \multirow[t]{2}{*}{ Treatment } & \multicolumn{4}{|c|}{ Per cent of dead leaves in a plant } \\
\hline & 270DAP & 315 AP & 360 DAP & Mean \\
\hline $\mathbf{T}_{1}$ & $\begin{array}{l}47.87 \\
(43.77) \\
\end{array}$ & $\begin{array}{l}33.20 \\
(35.17)\end{array}$ & $\begin{array}{l}30.90 \\
(33.74)\end{array}$ & 41.60 \\
\hline $\mathbf{T}_{2}$ & $\begin{array}{l}41.87 \\
(40.30)\end{array}$ & $\begin{array}{l}32.00 \\
(34.46)\end{array}$ & $\begin{array}{l}37.30 \\
(37.54)\end{array}$ & 38.37 \\
\hline $\mathbf{T}_{3}$ & $\begin{array}{l}45.80 \\
(42.59)\end{array}$ & $\begin{array}{l}33.20 \\
(35.17)\end{array}$ & $\begin{array}{l}40.00 \\
(39.36)\end{array}$ & 42.93 \\
\hline $\mathbf{T}_{4}$ & $\begin{array}{l}48.47 \\
(44.11)\end{array}$ & $\begin{array}{l}34.70 \\
(36.05)\end{array}$ & $\begin{array}{l}32.10 \\
(34.51)\end{array}$ & 45.97 \\
\hline $\mathbf{T}_{5}$ & $\begin{array}{l}49.97 \\
(44.96) \\
\end{array}$ & $\begin{array}{l}33.00 \\
(35.08) \\
\end{array}$ & $\begin{array}{l}33.30 \\
(35.19) \\
\end{array}$ & 41.93 \\
\hline$T_{6}$ & $\begin{array}{l}35.90 \\
(36.74)\end{array}$ & $\begin{array}{l}28.90 \\
(32.48)\end{array}$ & $\begin{array}{l}29.20 \\
(32.68)\end{array}$ & 33.47 \\
\hline $\mathbf{T}_{7}$ & $\begin{array}{l}49.77 \\
(44.87) \\
\end{array}$ & $\begin{array}{l}35.70 \\
(36.63)\end{array}$ & $\begin{array}{l}41.10 \\
(39.29)\end{array}$ & 45.43 \\
\hline $\mathbf{T}_{8}$ & $\begin{array}{l}38.37 \\
(38.27)\end{array}$ & $\begin{array}{l}31.00 \\
(33.76)\end{array}$ & $\begin{array}{l}30.20 \\
(33.21)\end{array}$ & 36.63 \\
\hline $\mathbf{T}_{9}$ & $\begin{array}{l}54.57 \\
(47.68) \\
\end{array}$ & $\begin{array}{l}36.60 \\
(37.23) \\
\end{array}$ & $\begin{array}{l}36.00 \\
(36.84) \\
\end{array}$ & 43.00 \\
\hline $\mathbf{T}_{10}$ & $\begin{array}{l}55.40 \\
(48.13)\end{array}$ & $\begin{array}{l}35.40 \\
(41.55)\end{array}$ & $\begin{array}{l}33.90 \\
(41.49)\end{array}$ & 54.53 \\
\hline SEm \pm & 1.908 & 1.317 & 1.710 & \\
\hline C.D. 0.05 & 5.670 & 3.912 & 5.079 & \\
\hline
\end{tabular}

Note: Data in the parentheses indicate angular transformed values

Minimum mean percentage $(33.47 \%)$ of dead leaves in a plant was recorded in plants treated with biocontrol agents as both sucker treatment and soil application followed by only soil application of both bioagents $(36.63$ $\%)$ where as control plants recorded maximum $(54.53 \%)$ value of the character (Table 2). This was supported by study conducted by Gareia de Salamone et al., (2001) and saravan and Muthuswamy (2006). In conclusion, sucker treatment before planting and soil drenching twice at 60 and 180 DAP with biocontrol agents Trichoderma viride and Pseudomonas fluorescens found to be the most effective in reducing the disease incidence and intensity in comparison to fungicides. It seems that biocontrol agents are highly useful in tackling the menace of fusarium wilt disease in banana growing areas of the world.

\section{References}

Alves, E.J., Shepherd, K., Dantas, J.L.L. 1987. Cultivation of bananas and plantain in Brazil and needs for improvement. In: Perseley, G.J., DeLanghe, E.A. (Eds.), Banana and Plantain Breeding Strategies, ACIAR Proceedings No. 21, Canberra, Australia, p.187.

Alabouvette, C., Lemanceau, P., Steinberg, C. 1993. Recent advances in the biological control of Fusarium wilts. Pesticides Sci., 37: 365-373.

Dowling, D.N., O'Gara, F. 1994. Metabolites of Pseudomonas involved in the biocontrol of plant disease. Trends in Biotechnol., 3: 121-141.

Hwang, S.C. 1985. Ecology and control of Fusarium wilt of banana. Plant Protection Bull., (Taiwan), 27: 233-245. 
Lakshmanan, P., Selvaraj, P., Mohan, S. 1987. Efficiency of different methods for the control of Panama disease. Trop. Pest Manage., 33: 373-376.

Moore, N.Y., Pegg, K.G., Bentley, S., Smith, L.J. 1999. Fusarium wilt of banana: global problems and perspectives. In: Molina, A.B., Masdek, N.H.N. Liew, K.W, (eds). Banana Fusarium Wilt Management: Towards Sustainable Cultivation. Proceedings of the International Workshop on Banana Fusarium Wilt Disease. Kuala Lumpur, Malaysia: INIBAP, 11-30.

García de Salamone, I.E., Hynes, R.K., Nelson, L.M. 2001. Cytokinin production by plant growth promoting rhizobacteria and selected mutants. Canadian J. Microbiol., 47: 404-411.

Ploetz, R.C., Herbert, J., Sebasigari, K.J., Hernandez, H., Pegg, K.G., Ventura, J.A. Mayato, L.S. 1990. Importance of Fusarium wilt in different banana growing regions. Fusarium Wilt of Banana, 9-26.

Stover, R.H. 1962. Fusarium wilt (Panama disease) of bananas and other Musa species. Phytopathol., No.4, CMI, Kew.

Su, H.J., Hwang, S.C., Ko, W.H. 1986. Fusarial wilt of Cavendish bananas in Taiwan. Plant Dis., 70: 814-818.

Saravanan, T., Muthusamy, M. 2006. Influence of Fusarium oxysporum f. sp. cubense (e.f. smith) Snyder and Hansen on 2, 4- diacetylphloroglucinol production by Pseudomonas fluorescens migula in banana rhizosphere. J. Plant Protection Res., 46: 241-254.

Sivamani, E., Gnanamanickam, S.S. 1988. Biological control of Fusarium oxysporum f.sp. cubense in banana by inoculation with Pseudomonas fluorescens. Plant Soil, 107: 3- 9.

Thangavelu, R., Mustaffa, M.M. 2010. A Potential isolate of Trichoderma viride NRCB1and its mass production for the effective management of Fusarium wilt disease in banana. Tree and Forestry Sci. Biotechnol., 4 (Special issue 2): 7684.

Rajappan, K., Vidhyasekaran, P., Sethuraman, K., Baskaran, T.L. 2002. Development of powder and capsule formulations of Pseudomonas fluorescens strain Pf-1 for the control of banana wilt. Zeitschrift für Pflanzenkrankheiten und Pflanzenschutz., 109: 80-87.

Viljoen, A. 2002. The status of Fusarium wilt (Panama disease) of banana in South Africa. South African J. Sci., 98: 341344.

Wardlaw, C.W. 1961. Banana diseases, inclzuding Plantains and Abaca. Longmans, Green and Co. Ltd, London: 648.

\section{How to cite this article:}

Pushpavathi, Y., and Dash, S.N. 2017. Use of Biocontrol Agents: A Potential Alternative to Fungicides for Fusarium Wilt Management of Banana. 2017. Int.J.Curr.Microbiol.App.Sci. 6(7): 651-655. doi: https://doi.org/10.20546/ijcmas.2017.607.079 